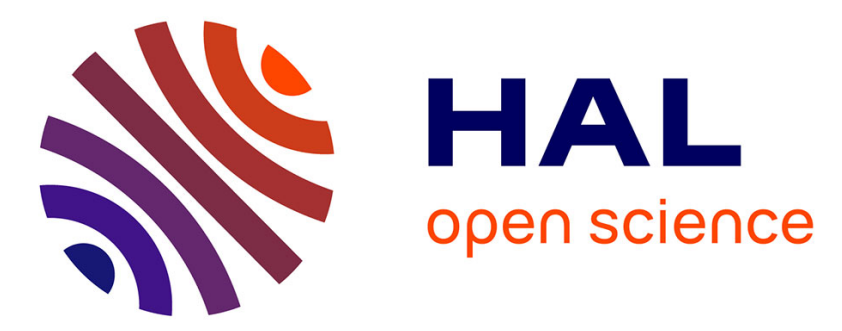

\title{
Histological study of organogenesis in Cucumis melo L. after genetic transformation: why is it difficult to obtain transgenic plants?
}

\author{
V Chovelon, V. Restier, N. Giovinazzo, Catherine Dogimont, J. Aarouf
}

\section{To cite this version:}

V Chovelon, V. Restier, N. Giovinazzo, Catherine Dogimont, J. Aarouf. Histological study of organogenesis in Cucumis melo L. after genetic transformation: why is it difficult to obtain transgenic plants? Plant Cell Reports, 2011, 30 (11), pp.2001-2011. 10.1007/s00299-011-1108-9 . hal-01332269

\author{
HAL Id: hal-01332269 \\ https://hal.science/hal-01332269
}

Submitted on 29 May 2020

HAL is a multi-disciplinary open access archive for the deposit and dissemination of scientific research documents, whether they are published or not. The documents may come from teaching and research institutions in France or abroad, or from public or private research centers.
L'archive ouverte pluridisciplinaire HAL, est destinée au dépôt et à la diffusion de documents scientifiques de niveau recherche, publiés ou non, émanant des établissements d'enseignement et de recherche français ou étrangers, des laboratoires publics ou privés.

\section{(ㅇ)(1) $\$$}

Distributed under a Creative Commons Attribution - NonCommerciall 4.0 International 


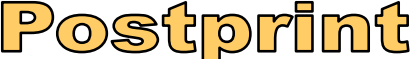

Version définitive du manuscrit publié dans / Final version of the manuscript published in : Plant Cell Reports, 2011, vol 30 (11) :2001-2011 DOI: 10.1007/s00299-011-1108-9

Histological Study of Organogenesis in Cucumis melo L. after genetic transformation: why is it difficult to obtain transgenic plants?

\section{Chovelon 'V. Restier` N. Giovinazzo ‘ C. Dogimont J. Aarrouf}

INRA Avignon, UR1052, Unité de Génétique et d'Amélioration des Fruits et Légumes, BP 94, 84143 Montfavet Cedex, France

e-mail : Veronique.chovelon@avignon.inra.fr

J. Aarrouf

UAPV Avignon, Laboratoire de Physiologie des Fruits et des Légumes, Pôle Agrosciences, 301 Rue Baruch de Spinoza, BP 21239, 84916 Avignon cedex 9, France

e-mail : jawad.aarrouf@univ-avignon.fr 


\section{Abstract}

Melon (Cucumis melo L.) is widely considered as a recalcitrant species for genetic transformation. In this study, we developed different regeneration and transformation protocols and we examined the regeneration process at different steps by histological studies. The highest regeneration rate $(1.13 \pm 0.02$ plants per explant $)$ was obtained using cotyledon explants of the 'Védrantais' genotype on Murashige and Skoog (MS) medium supplemented with $0.2 \mathrm{mg} / \mathrm{l}$ 6-benzylaminopurine (BAP) and $0.2 \mathrm{mg} / \mathrm{l}$ dimethylallylaminopurine (2-iP). Agrobacterium tumefaciens-mediated transformations with the uidA reporter gene were realized on cotyledon explants cultivated in these conditions: $70-90 \%$ of explants expressed a transient GUS activity during the early stages of regeneration, however, only few transgenic plants were obtained (1.8-4.5\% of stable transformation with the GV2260pBI101 strain). These results revealed a low capacity of melon GUS-positive cells to regenerate transgenic plants. To evaluate the influence of the Agrobacterium infection on plant regeneration, histological analyses were conducted on explants 2, 7, 15 and 28 days after co-culture with the GV2260pBI101 strain. Genetic transformation occurred in epidermal and sub-epidermal cells and reached the meristematic structures expressing a high level of GUS activity during 14 days of culture; but after this period, most of the meristematic structures showed premature cell vacuolization and disorganization. This disruption of the GUS-positive meristematic areas could be responsible of the difficulties encountered to regenerate melon plants after genetic transformation.

Keywords: Cucumis melo L. . Agrobacterium tumefaciens . Genetic transformation. NptII and uidA genes 


\section{Introduction}

Cucumis melo L. is one of the main species within the Cucurbitaceae. Other species in the family include, i.e., cucumber, watermelon, and squashes. They represent the second group of horticultural species after the Solanaceae and they have been the subject of intense breeding and research since the seventeenth century. Melon is widespread in the world with a large genetic diversity in cultivated and wild genotypes. It is a diploid species, with $\mathrm{n}=12$ chromosomes and a relatively small genome, with an estimated size of $450 \mathrm{Mbp}$. Melon plant breeding has been done by traditional hybridization techniques, but development of new cultivars with high levels of disease resistance, flavour and sweetness is still required. Genomic tools exist for this species and plant biotechnology can be used to introduce genes and transfer novel characteristics for breeding or functional validation of candidate genes involved in horticultural traits. The two major pre-requisites for genetic transformation through Agrobacterium tumefaciens are the availability of a reliable plant regeneration system and a suitable method for transformation. Since the first report of successful transformation of melon (Fang and Gumet 1990), more than 40 in vitro melon regeneration protocols have been described on a wide range of melon cultivars, using organogenesis or somatic embryogenesis pathways (Guis et al. 1997, 2000; Ezura et al. 2000; Kintzios et al. 2002; Yalcin-Mendi et al. 2004; Akasaka-Kennedy et al. 2004; Castelblanque et al. 2008). However, several biological and physical factors affect the efficiency rate and melon regeneration remains difficult and highly dependent of the genotype (Galperin et al. 2003; reviewed by Pech et al. 2007; NunezPalenius et al. 2008) and the explants source (Guis et al 2000). Morphological abnormalities, such as the presence of meristematic protuberances that fail to develop into normal shoots or plantlets without apical dominance, are frequently observed (Gaba et al. 1999; Liborio Stipp et al. 2001). Explants origin affects the ploidy level of the plants regenerated from melon tissue culture and high frequency of tetraploid regenerants is a common phenomenon (Adelberg et al. 1994; Nunez-Palenius et al. 2008).

Melon transformation has been successfully obtained with reporter genes (Fang and Grumet 1990; Gray et al. 1995; Akasaka-Kennedy et al. 2004) and several plant traits, such as virus resistance (Fang and Grumet 1993; Yoshioka et al. 1993; Gonsalvez et al. 1994; Fuchs et al. 1997; Huttner et al. 2001; Yalcin-Mendi et al. 2004; Gaba et al. 2004 ; Wu et al 2010), salt tolerance (Bordas et al. 1997) and long fruit shelf life (Ayub et al. 1996; Ezura et al. 1997; Silva et al. 2004; Curuk et al. 2005; Papadopoulou et al. 2005; Nunez-Palenius et al. 2006) have been incorporated into different melon types or into other Cucurbitaceae (Han et al. 2005; Ntui et al. 2010). Transformation capacity varies widely according to the cultivar 
and the target explants and false positive regenerants are commonly obtained (Guis et al 1997). Even if some exceptional results were reported with particular genotypes (Galperin et al. 2003; Nunez-Palenius et al. 2006), transformation efficiency remains relatively low, and generally ranged from 0.7 to 3\% (Gaba et al. 1992; Bordas et al. 1997; Guis et al. 2000; Akasaka-Kennedy et al. 2004; Yalcin-Mendi et al. 2004; Curuk et al. 2005; Castelblanque et al. 2008) and can reach 7\% (Fang and Grumet 1990). However, environmental and hormonal requirements for melon regeneration continue to be poorly understood and developing simple and routine procedures to regenerate and transform all melon genotypes is still challenging. Essential steps to be optimized are the regeneration capability of explants, the efficiency of cell transformation and the efficiency of plant regeneration from transformed cells.

In the present investigation, we evaluated the regeneration efficiency of different melon genotypes on two culture media in order to determine which combination provides the highest regeneration rate. We studied the effect of different Agrobacterium strains on the regeneration capability of the transformed plants and we observed, by histological analysis the development of transgenic cells during organogenesis from early stages after Agrobacterium exposure.

\section{Materials and Methods}

Plant material

Twelve distinct and unrelated genotypes of C. melo were used in this study: a Charentais type line 'Védrantais' (Vilmorin release), a hermaphrodite line of an Oriental type 'Paul' (Martin et al. 2009) and ten other genotypes from different botanical groups (cantalupensis, chandalak, reticulatus, inodorus and chate) and geographical origins (France, Bulgaria, Brazil, Russia, China, USA, Turquey and Italy). Seeds were sterilized $30 \mathrm{~s}$ in $70^{\circ}$ alcohol and rinsed thrice with sterile water. Seeds were manually peeled to remove the seed coat and surface-sterilized in $2.5 \%$ calcium hypochlorite containing $0.1 \%$ tween 20 for 5 min and rinsed with sterile water. The sterilized seeds were placed on Murashige and Skoog (MS) medium (Murashige and Skoog 1962) at $28^{\circ} \mathrm{C}$ in the dark for 4 days and then at light under a 16-h photoperiod provided by cool-white fluorescent lamps $\left(60 \mu \mathrm{E} / \mathrm{m}^{2}\right.$ per s photon irradiance) at $26-28^{\circ} \mathrm{C}$. 
Plant regeneration

Cotyledons and young leaves, from 4 and 13 days-old seedling respectively, were used as explants for shoot regeneration. They were cut transversely in four equal pieces and placed on two different regeneration media: MS medium with $0.2 \mathrm{mg} / 1$ 6-benzylaminopurine (BAP) and $0.2 \mathrm{mg} / \mathrm{l}$ dimethyl-allylaminopurine (2-iP) (Guis et al. 2000) or MS medium with $1.12 \mathrm{mg} / \mathrm{l}$ 6benzylaminopurine (BAP), $0.88 \mathrm{mg} / 1$ indole-3-acetic acid (IAA) and $0.26 \mathrm{mg} / 1$ abscisic acid (ABA) (Yalcin-Mendi et al. 2004). Explants were sub-cultured every 2 weeks on fresh medium. Regenerated shoots were excised, transferred on elongation medium [MS medium with $0.2 \mathrm{mg} / 1 \mathrm{BAP}$ and $0.1 \mathrm{mg} / 1$ gibberellic acid $\left(\mathrm{GA}_{3}\right)$ ] during 2-3 weeks and placed on MS medium free of hormones for rooting. All media were supplemented with $30 \mathrm{~g} / 1$ sucrose, $7 \mathrm{~g} / 1$ Bacto agar (Difco Laboratories) and the $\mathrm{pH}$ was adjusted to 5.7 before autoclaving $\left(120^{\circ} \mathrm{C}, 20\right.$ min). Plant regeneration and development were conducted in a growth chamber under a $16-\mathrm{h}$ photoperiod provided by cool-white fluorescent lamps $\left(60 \mu \mathrm{E} / \mathrm{m}^{2}\right.$ per s photon irradiance $)$ at $26-28^{\circ} \mathrm{C}$.

Agrobacterium inoculation and plant transformation

Different A. tumefaciens strains were used for the transformation of melon cotyledon explants: two C58 strains (AGL-1 and GV2260 containing the binary vector pBI101) and a TiAch5 strain (LBA4404 with the binary vector pBI121) harboring the uidA reporter gene and the selectable kanamycin resistance NptII gene under control of the CaMV 35S promoter. The different Agrobacterium strains were grown overnight in Luria-Bertani (LB) medium (pH 7.5) with $50 \mathrm{mg} / \mathrm{l}$ kanamycin, $50 \mathrm{mg} / \mathrm{l}$ rifampycin (for LBA4404pBI121) and supplemented with $50 \mathrm{mg} / 1$ ampicillin (for AGL-1pBI101 and GV2260pBI101). After centrifugation (10 min at 5,000 rpm at $4^{\circ} \mathrm{C}$ ) the Agrobacterium suspensions were adjusted at $\mathrm{OD}_{600}: 0.3\left(10^{6}-10^{8}\right.$ bacteria/ml $)$ with $\mathrm{MS}$ medium containing $200 \mathrm{mg} / 1 \mathrm{KH}_{2} \mathrm{PO}_{4}, 0.9 \mathrm{mg} / \mathrm{l}$ thiamin and $39 \mathrm{mg} / \mathrm{l}$ acetosyringone. Cotyledon explants were immersed in the Agrobacterium suspension for $20-30 \mathrm{~min}$ with orbital shaking $(50 \mathrm{rpm})$ at $28^{\circ} \mathrm{C}$. Explants were blotted onto sterile filter paper to remove the excess of bacterial suspension, transferred to regeneration medium (MS medium with $0.2 \mathrm{mg} / \mathrm{l} \mathrm{BAP,} 0.2 \mathrm{mg} / 1$ 2-iP) containing $100 \mu \mathrm{M}$ acetosyringone for a 48 -h co-cultivation period at $28^{\circ} \mathrm{C}$ in the dark. Subsequently, the explants were rinsed thrice in sterile water, blotted dry and transferred to selective regeneration medium (MS medium with $0.2 \mathrm{mg} / 1 \mathrm{BAP}, 0.2 \mathrm{mg} / 1$ 2-iP, $225 \mathrm{mg} / 1$ timentin and $100 \mathrm{mg} / 1 \mathrm{kanamycin}$ ) and cultured under a $16-\mathrm{h}$ photoperiod at $26-28^{\circ} \mathrm{C}$. Explants were sub- 
cultured on fresh medium every 2 weeks and shoots were excised and transferred to elongation medium (MS medium with $0.2 \mathrm{mg} / 1 \mathrm{BAP}$ and $0.1 \mathrm{mg} / 1 \mathrm{GA}_{3}$ ) supplemented with the same antibiotics during 2-3 weeks. Developed plantlets were placed on MS medium free of hormones for rooting. GUS-positive plants were transferred into soil and cultivated under a confined greenhouse.

Histochemical GUS assay

GUS expression was assessed on explants or on young leaf of the plants regenerated after transformation with the different Agrobacterium strains by performing histochemical assays as described by Jefferson et al. (1987).

\section{Histological studies}

Histological analyses of the organogenesis process were realized at different dates $(2,7,14$ and 28 days) by cytological observations on 5 GUS-positive explants infected by GV2260pBI101 and 5 non-inoculated explants as control. Explants were immersed in a cold fixative (formalin-acetic acid-ethanol at 1:1:8 V/V/V) during $48 \mathrm{~h}$ at $4{ }^{\circ} \mathrm{C}$ (Aarrouf et al. $2008)$, rinsed in distilled water, dehydrated in ethanol series (25-50-70-85 and 100\%) and embedded in methacrylate resin (Kit Technovit 7100, Wehrheim, Germany). Sections (3 $\mu \mathrm{m}$ thickness) were serially cut with a retraction microtome, collected on microscope slides, colored with toluidine blue and observed with a light microscope. The photographic images were captured using an automatic camera.

Detection of the uidA and NptII reporter genes by polymerase chain reaction

Genomic DNA was extracted from young leaf tissue of putative transgenic melon plantlets following the method of Fulton et al (1995). The presence of the transgene was checked by PCR using specific primers of the uidA gene (forward primer: 5'AACTGGACAAGGCACTAGCG-3' and reverse primer: 5' CACCGAAGTTCATGCCAGTC-3'; melting temperature $62^{\circ} \mathrm{C}$ ) and specific primers of the NptII gene (forward primer: 5'-CCGGCTACCTGCCCATTC-3' and reverse primer: 5'GCGATAGAAGGCGATGCG-3'; melting temperature $53^{\circ} \mathrm{C}$ ). PCR were performed in 25 $\mu \mathrm{L}$ reaction volume containing $2 \mathrm{ng}$ DNA, 1 x PCR reaction buffer, $1.5 \mathrm{mM} \mathrm{MgCl} 2,0.08 \mathrm{mM}$ dNTP mixture, $0.4 \mu \mathrm{M}$ of each primer, 0.5 unit of Taq DNA polymerase (Go Taq Promega) 
and distilled water. The mixtures were transferred to a thermo cycler for amplification adopting the thermal profile: $4 \mathrm{~min}$ at $94^{\circ} \mathrm{C}$ and 30 cycles at $94^{\circ} \mathrm{C}$ for $30 \mathrm{~s}$, annealing at melting temperature for $1 \mathrm{~min}$, and synthesis at $72^{\circ} \mathrm{C}$ for $45 \mathrm{~s}$, followed by a final extension at $72^{\circ} \mathrm{C}$ for $10 \mathrm{~min}$. The amplified PCR products $(1,200 \mathrm{pb}$ for the uidA gene and $400 \mathrm{pb}$ for the NptII gene) were subjected to electrophoresis in a 1\% agarose gel (Tris-acetate-EDTA buffer $\mathrm{pH}$ 8.0) for $45 \mathrm{~min}$ at 100 volts and visualized by ultraviolet light after immersion $20 \mathrm{~min}$ in ethidium bromide solution.

Ploidy estimation

The ploidy level of regenerated plants was determined by flow cytometry and confirmed by phenotypic characteristics. Crude samples of nuclei were prepared from the leaves of acclimatized plants chopped in $1 \mathrm{ml}$ of DAPI and filtered according to the method of Galbraith et al. (1991). The DNA content of the isolated nuclei was analyzed with a flow cytometer (Partec) calibrated from the nuclei of young leaves of diploid plants obtained from seed. The noise signals derived from subcellular debris were eliminated by gating. The isolated populations of plant nuclei gave characteristic peaks of fluorescence emission, the lowest peak corresponding to $2 \mathrm{C}$ nuclei, and the other peaks representing $4 \mathrm{C}$ and $8 \mathrm{C}$ nuclei. Ploidy level of the transgenic plants was confirmed by phenotypic observations of plants cultured in a confined greenhouse. According to Ezura et al. (1992) and Nugent (1994), the phenotype of tetraploid melon plants is characterized by having large male and hermaphrodite flowers, protruding stigmas, low fertility, thickened leaves, short internodes and round seeds.

\section{Results}

Effect of genotype, explants source and culture medium on plant regeneration

Independent experiments of regeneration were completed to investigate the effect of genotype, explants source and culture medium on regeneration efficiency. Leaf and cotyledon explants from the two genotypes 'Védrantais' and 'Paul' were cultivated on two media described by Guis et al. (2000) and Yalcin-Mendi et al. (2004) respectively, with 70-220 explants for each genotype/explants source/medium combination. The percentage of plant regeneration was scored after 75-90 days. Very low regeneration rates were obtained with the different explants sources of both genotypes placed on MS medium supplemented with 1.12 $\mathrm{mg} / \mathrm{l} \mathrm{BAP}, 0.88 \mathrm{mg} / 1 \mathrm{IAA}$ and $0.26 \mathrm{mg} / \mathrm{l} \mathrm{ABA}$ (Table 1). The highest regeneration rates were 
obtained from 'Védrantais' cotyledon explants cultured on MS medium supplemented with $0.2 \mathrm{mg} / 1 \mathrm{BAP}$ and $0.2 \mathrm{mg} / 1$ 2-iP. In this condition, $50-80 \%$ of explants gave shoots with a final mean rate of 1.13 elongated plantlets regenerated per explant. On the same medium, 'Védrantais' leaf explants regeneration was 10 times lower and ranged around 0.11 plantlets per explant, with only $13-15 \%$ of explants giving shoots. Low results were also obtained on this medium from 'Paul' cotyledon explants ( 0.15 plantlets per explant) or leaf explants $(0.06$ plantlets per explant). Melon plants regenerated through plant tissue culture are very susceptible to an increase in ploidy level. Therefore, flow cytometry analyses were performed to determine the ploidy level of explants and regenerated plants. All the explants providing from leaf were diploid, whereas explants from cotyledon were mixoploid (diploid and tetraploid cells). It was found that $87.8 \%$ of regenerated plants issued from leaf explants were diploid, whereas only $47 \%$ of plants regenerated from cotyledon explants (shoots could have arisen from either diploid or tetraploid cells).

Using the best experimental conditions (cotyledon explants on MS medium with BAP and 2-iP), the regeneration capacity of 11 melon genotypes was evaluated. The results showed that the regeneration response is highly genotype dependent and ranged from 0.05 to 1.12 plants regenerated per explant (Table 2). The 'Védrantais' genotype gives the highest regeneration rate.

\section{Effect of Agrobacterium infection on regeneration and transformation efficiency}

Independent experiments of transformation were realized with three different Agrobacterium strains (AGL-1pBI101, GV2260pBI101 and LB4404pBI121) on 'Vedrantais' cotyledon explants in comparison with control experiments on uninfected explants (Table 3). In vitro cultures were followed during 90 days and some explants and all the regenerated plants were tested by histochemical GUS assays (Fig. 2a). 70 to $90 \%$ of tested explants exhibited a transient GUS activity 14 days after Agrobacterium exposure and the presence of blue protuberances and shoots was observed at 28 days (Fig. 1). The plant regeneration rates obtained from cotyledon explants after exposure to the different Agrobacterium strains were significantly reduced $(0.075 \pm 0.02$ with LB4404pBI121 to $0.22 \pm 0.5$ with AGL-1pBI101) in comparison with the uninfected control explants $(1.81 \pm 0.88)$. Significant differences of transformation efficiencies were observed with the different Agrobacterium strains and higher results were obtained with GV2260pBI101 $(3.0 \% \pm 1.10)$ (Table 3). Transgenic plants were transferred to soil and cultivated in a confined greenhouse (Fig. 2c). The ploidy level was assessed by flow cytometry and confirmed by phenotypic observations: the majority of 
transgenic plants obtained from cotyledon explants were tetraploid and only $15 \%$ of them were diploid. Flowers expressed GUS activity both in ovule (Fig. 2d, e) and pollen (Fig. 2f). Segregant transgenic plants and homozygous transgenic lines were obtained by self pollination of the diploid plants.

Histological analysis of the regeneration process

In order to evaluate the influence of Agrobacterium infection on plant regeneration, histological analyses and cytological observations were realized during different phases of in vitro culture (at 2, 7, 14 and 28 days) on explants inoculated with the GV2260pBI101 strain and on uninfected explants as control. Observations of non-transformed explants showed that epidermal cells are the source of organogenesis and many small independent areas are involved. These cells formed meristematic structures between 7 and 14 days after transfer on the regeneration medium (Fig. 3a) and developed shoots at 28 days (Fig. 3b); plantlets were obtained in 5-6 weeks. For Agrobacterium-inoculated explants, genetic transformation occurred in epidermal and sub-epidermal cells. The presence of cells with GUS activity was observed at 7 days (Fig. 3c) and reached the meristematic structures expressing a high level of GUS activity at 14 days (Fig. 3d). However, after 28 days cytological observations showed an abnormal development of the meristematic structures with cell vacuolization and dislocation (Fig. 3e, f). The disorganization of the transformed meristematic areas may explain the important reduction of plant regeneration after Agrobacterium infection.

\section{Discussion}

The development of a breeding program associated to biotechnological tools or the functional characterization of candidate genes involved in agricultural traits depend upon the development of an efficient in vitro plant regeneration and transformation system. Advances were made to better understanding the metabolic processes correlated with regeneration, but determining the conditions for in vitro plant cultures is still empirical and can be difficult to achieve for some plant species or genotypes. Successes on melon organogenesis were reported in literature with regeneration rates ranging from 0.3 to 2 plants elongated per explant (Guis et al. 2000; Yalcin-Mendi et al. 2004; reviewed by Pech et al. 2007) with a percentage of explants developing shoots ranging from 0 to $44 \%$ depending on cultivars (Nunez-Palenius et al. 2008). These rates are relatively low compared to other plants, such as tomato or potato for instance, for which regeneration frequencies from 40 to $98 \%$ with 3-12 
shoots per explant were reported (Yee et al. 2001; Abu-El-Heba et al. 2008). The in vitro responses of plant tissues are affected by different factors. The origin of the explants, the hormonal balance, the environmental conditions and the genotype were shown to be critical for the melon regeneration process. In this experiment, we compared two protocols on two explants sources (leaf and cotyledon) of two genetically distant melon accessions. We then compared the regeneration rate of 11 accessions representative of the worldwide melon diversity using the most successful protocol. The MS medium added with BAP and 2-iP was shown to be well adapted to the regeneration from cotyledon explants of the charentais melon 'Védrantais' (1.13 \pm 0.02 plants regenerated per explant). In contrast, very low regeneration rates were obtained from the oriental melon 'Paul'. Using 'Védrantais' a higher regeneration frequency of de novo shoots was obtained from cotyledon explants (50-84\% of explants developing shoots) than from leaf explants (14-15\%). 87.8\% of the plants regenerated from leaf explants and $47 \%$ of the plants obtained from cotyledon explants were diploid. Explants providing from cotyledon were mixoploid and shoots could have arisen from either diploid or tetraploid cells (Gonsalvez et al. 1994). These results confirm the importance of the explants source to affect the regeneration rate and induce somaclonal variations in plants issued from melon tissue cultures (Adelberg et al. 1994; Guis et al. 2000). Melon varieties (reticulatus, cantalupensis, inodorus, chate etc.) and commercial cultivars exhibit differences in their regeneration ability under the same in vitro conditions. The great variability in melon is the most important factor determining regeneration potential and the results obtained with the different accessions tested confirm the need to adapt the regeneration protocol to each melon genotype.

Melon genetic transformation mediated by A. tumefaciens remains difficult and the efficiency rates obtained generally range from 0.7 to 3\% (Dong et al. 1991; Bordas et al. 1997; Guis et al. 2000; Yalcin-Mendi et al. 2004; Castelblanque et al. 2008) and exceptionally reach 7\% (Fang and Grumet 1990) or 12\% (Nunez-Palenius et al. 2006). In many cases most of the recovered transgenic plants had somaclonal variation especially ploidy changes or morphogenetic altered characteristics (Gonsalvez et al. 1994). Genetic transformation is the result of a combination of factors such as Agrobacterium strain, binary vector structure, selectable marker and gene construct, which could be modified to provide optimal conditions and improved transformation efficiencies. Strains of Agrobacterium used for plant transformation are defined by their chromosomal background and resident Ti-plasmid (Hellens et al. 2000). The C58 chromosomal background is often used for plant transformation and we showed its advantage for melon transformation. In our experiments 
higher transformation efficiencies were obtained with the two C58 strains GV2260pBI101 and AGL-1pBI101 than with the LBA4404pBI121 strain. However, these transformation rates (ranged between 1.8 and $4.5 \%$ for GV2260pBI101) were still relatively low although the transient transformation of cotyledon explants was highly efficient with 70-90\% of explants exhibiting a GUS activity 14 days after Agrobacterium exposure. These results showed a lower regeneration ability of the transformed cells suggesting an incapacity for melon cells to be competitive both for transformation and regeneration. As reported previously on watermelon and pepper (Yalcin-Mendi et al. 2003; Wolf et al. 2001), we showed by cytological observations that epidermal and sub-epidermal cells are the source of melon organogenesis. The histological analysis of explants 10 days after the infection by Agrobacterium brought to light a disorganization of the transformed meristematic areas, which may explain the difficulties encountered to regenerate melon plants after genetic transformation and the important fall in the regeneration rate observed between infected and uninfected explants (more than 10 times less). This phenomenon could be related to different hypotheses. Agrobacterium tumefaciens is a soil-borne phytopathogen and, even if the strains used for gene transfer were "disarmed" (lacking oncogenes), their nature and their virulence power are important factors influencing the frequency of transformation and the regeneration of recalcitrant species (Veena Jiang et al. 2003). The infection of plant tissues by Agrobacterium induces the expression of host genes involved in mediating transformation, suppresses plant defence responses, and hijacks the plant metabolic machinery towards the TDNA integration into the plant genome (Veena Jiang et al. 2003; Gelvin 2003; Anand et al. 2007). Variation in response of plant tissues following Agrobacterium exposure has been reported and attributed to different causes as the ability of the bacterium to attach plant cells (Lippincott et al. 1977) or the efficiency of the T-DNA transfer machinery (Nam et al. 1997; Gelvin 2003). Presence of nuclear DNA fragmentation and apoptotic cell death were reported on recalcitrant species like maize and banana (Hansen 2000; Khanna et al. 2007). It has also been demonstrated that ethylene, which regulates many aspects of plant development and stress response, inhibits Agrobacterium-mediated gene transfer (Davis et al. 1992; Ezura et al. 2000). Genetic transformation of "Egusi" melon (Colocynthis citrullus L.) was enhanced by co-introduction of the ACC deaminase gene reducing ethylene production of explants after Agrobacterium infection (Ntui et al. 2010). For recalcitrant species like melon, the disorganization of meristematic structures following the exposure of explants to Agrobacterium remains the major obstacle to develop efficient transformation technology. Further investigations should be realized to find other Agrobacterium strains (with different Ti-plasmid or binary vector) allowing good cell transformation but less damage on melon 
plant regeneration and to limit the ethylene production of explants in response to the bacterial infection. Alternative transformation methods such as biolistic (Gonsalvez et al. 1994; Gray et al. 1995; Schulze et al. 1995) or pollen-tube pathway (Zhou et al. 1983; Wen-Shaw Chen et al. 1998; Yang et al. 2009; Hao et al. 2010) yet applied on melon, could also been developed for melon genetic transformation. 
Table 1 Effect of culture medium, genotype and explants source on melon regeneration

\begin{tabular}{|c|c|c|c|c|c|c|c|}
\hline Culture media & Genotype & $\begin{array}{l}\text { Explant } \\
\text { source }\end{array}$ & $\begin{array}{l}\text { Number of } \\
\text { explants in } \\
\text { culture }\end{array}$ & $\begin{array}{l}\text { Number of } \\
\text { explants } \\
\text { with shoots }\end{array}$ & $\begin{array}{l}\text { Number of } \\
\text { regenerated } \\
\text { plants }\end{array}$ & $\begin{array}{l}\% \text { of } \\
\text { diploid } \\
\text { plants }\end{array}$ & $\begin{array}{l}\text { Regeneration } \\
\text { rate }^{\mathrm{a}}\end{array}$ \\
\hline \multirow{6}{*}{$\begin{array}{l}\text { Regeneration } \\
\text { medium } \\
\text { (Yalcin-Mendi }_{\text {et al 2004) }}\end{array}$} & \multirow[t]{3}{*}{ Védrantais } & cotyledon & 70 & 3 & 5 & \multirow[t]{2}{*}{ Not tested } & \multirow[t]{2}{*}{$0.041 \pm 0.04$} \\
\hline & & & 100 & 2 & 2 & & \\
\hline & & leaf & 70 & 0 & 0 & - & 0 \\
\hline & \multirow[t]{3}{*}{ Paul } & cotyledon & 70 & 2 & 0 & \multirow[t]{2}{*}{ Not tested } & \multirow[t]{2}{*}{$0.018 \pm 0.02$} \\
\hline & & & 100 & 4 & 3 & & \\
\hline & & leaf & 70 & 0 & 0 & - & 0 \\
\hline \multirow{8}{*}{$\begin{array}{l}\text { Regeneration } \\
\text { medium } \\
\text { (Guis et al. }_{2000)^{\mathrm{c}}}\end{array}$} & \multirow[t]{4}{*}{ Védrantais } & cotyledon & 200 & 106 & 223 & \multirow[t]{2}{*}{47} & \multirow[t]{2}{*}{$1.13 \pm 0.02$} \\
\hline & & & 150 & 126 & 171 & & \\
\hline & & leaf & 70 & 11 & 8 & \multirow[t]{2}{*}{87.8} & \multirow[t]{2}{*}{$0.11 \pm 0.001$} \\
\hline & & & 220 & 30 & 25 & & \\
\hline & \multirow[t]{4}{*}{ Paul } & cotyledon & 70 & 14 & 10 & \multirow[t]{2}{*}{ Not tested } & \multirow[t]{2}{*}{$0.15 \pm 0.01$} \\
\hline & & & 70 & 12 & 11 & & \\
\hline & & leaf & 70 & 10 & 3 & \multirow[t]{2}{*}{ Not tested } & \multirow[t]{2}{*}{$0.06 \pm 0.02$} \\
\hline & & & 70 & 12 & 5 & & \\
\hline
\end{tabular}

${ }^{a}$ Regeneration rate: number of regenerated plants/number of explants in culture; \pm standard error

${ }^{\mathrm{b}} \mathrm{MS}$ medium with $1.12 \mathrm{mg} / \mathrm{l} \mathrm{BAP,} 0.88 \mathrm{mg} / \mathrm{IAA}, 0.26 \mathrm{mg} / \mathrm{l} \mathrm{ABA}$

${ }^{\mathrm{c}} \mathrm{MS}$ medium with $0.2 \mathrm{mg} / 1 \mathrm{BAP}$ and $0.2 \mathrm{mg} / 12$-iP

Table 2 Regeneration of different melon genotypes

\begin{tabular}{llllll}
\hline Genotype & Origin & Botanical group & $\begin{array}{l}\text { Number of } \\
\text { explants }^{\mathrm{a}}\end{array}$ & $\begin{array}{l}\text { Number of } \\
\text { regenerated plants }^{\text {rate }}\end{array}$ & $\begin{array}{l}\text { Regeneration } \\
\text { raten }^{\mathrm{b}}\end{array}$ \\
\hline Védrantais & France & Cantalupensis & 75 & 84 & 1.12 \\
\hline Gynadou & France & Cantalupensis & 72 & 15 & 0.21 \\
\hline Vidrinski Koravci & Bulgaria & Cantalupensis & 82 & 43 & 0.52 \\
\hline Gaucho 1 & Brasil & Cantalupensis & 82 & 23 & 0.28 \\
\hline Chandaljak & Russia & Chandalak & 78 & 44 & 0.56 \\
\hline China 51 & China & Reticulatus & 72 & 24 & 0.33 \\
\hline Smith perfect & USA & Reticulatus & 108 & 5 & 0.05 \\
\hline Casaba Golden B. & USA & Inodorus & 118 & 22 & 0.19 \\
\hline Kirkagac 637 & Turquey & Iinodorus & 65 & 5 & 0.08 \\
\hline Carosello & Italy & Cchate & 118 & 11 & 0.09 \\
\hline URS 187 & Russia & Unknown & 82 & 10 & 0.12 \\
\hline
\end{tabular}

${ }^{\mathrm{a} C}$ Cotyledon explants on MS medium with $0.2 \mathrm{mg} / \mathrm{l} \mathrm{BAP}$ and $0.2 \mathrm{mg} / 1$ 2-iP

${ }^{\mathrm{b}}$ Regeneration rate: number of regenerated plants/number of explants in culture 
Table 3 Transformation of 'Vedrantais' cotyledon explants using three different Agrobacterium strains

\begin{tabular}{|c|c|c|c|c|c|c|}
\hline $\begin{array}{l}\text { Agrobacterium } \\
\text { strain }^{\text {a }}\end{array}$ & Experiment & $\begin{array}{l}\text { Number } \\
\text { of } \\
\text { explants }\end{array}$ & $\begin{array}{l}\text { Number of } \\
\text { regenerated } \\
\text { plants }\end{array}$ & $\begin{array}{l}\text { Regeneration } \\
\text { rate }^{b}\end{array}$ & $\begin{array}{l}\text { Number of } \\
\text { transgenic } \\
\text { plants }^{\mathrm{c}}\end{array}$ & $\begin{array}{l}\text { Transformation } \\
\text { efficiency }{ }^{d}(\%)\end{array}$ \\
\hline \multirow{4}{*}{$\begin{array}{l}\text { Uninfected } \\
\text { cotyledons } \\
\text { (control) }\end{array}$} & 1 & 150 & 422 & 2.81 & - & - \\
\hline & 2 & 150 & 171 & 1.14 & - & - \\
\hline & 3 & 150 & 223 & 1.49 & - & - \\
\hline & Mean & - & - & $1.81 \pm 0.88$ & - & - \\
\hline \multirow[t]{3}{*}{ LBA4404pBI121 } & 1 & 300 & 19 & 0.06 & 1 & 0.3 \\
\hline & 2 & 250 & 23 & 0.09 & 1 & 0.4 \\
\hline & Mean & - & - & $0.075 \pm 0.02$ & - & $0.35 \pm 0.07$ \\
\hline \multirow[t]{3}{*}{ AGL-1pBI101 } & 1 & 155 & 29 & 0.19 & 1 & 0.6 \\
\hline & 2 & 170 & 45 & 0.26 & 4 & 2.0 \\
\hline & Mean & - & - & $0.22 \pm 0.5$ & - & $1.3 \pm 0.99$ \\
\hline \multirow[t]{6}{*}{ GV2260pBI101 } & 1 & 200 & 30 & 0.15 & 9 & 4.5 \\
\hline & 2 & 270 & 55 & 0.20 & 5 & 1.8 \\
\hline & 3 & 270 & 53 & 0.20 & 6 & 2.2 \\
\hline & 4 & 270 & 39 & 0.14 & 10 & 3.7 \\
\hline & 5 & 250 & 49 & 0.2 & 7 & 2.8 \\
\hline & Mean & - & - & $0.19 \pm 0.04$ & - & $3.0 \pm 1.10$ \\
\hline
\end{tabular}

${ }^{a}$ Cotyledon explants inoculated with different Agrobacterium strains containing the uidA and NptII genes

${ }^{\mathrm{b}}$ Regeneration rate: number of regenerated plants/number of explants ; \pm standard error

${ }^{\mathrm{c}}$ Number of transgenic plants obtained (tested by GUS assay and PCR for GUS-uidA and NptII genes)

${ }^{\mathrm{d}}$ Transformation efficiency: number of transgenic plants regenerated from 100 inoculated explants 

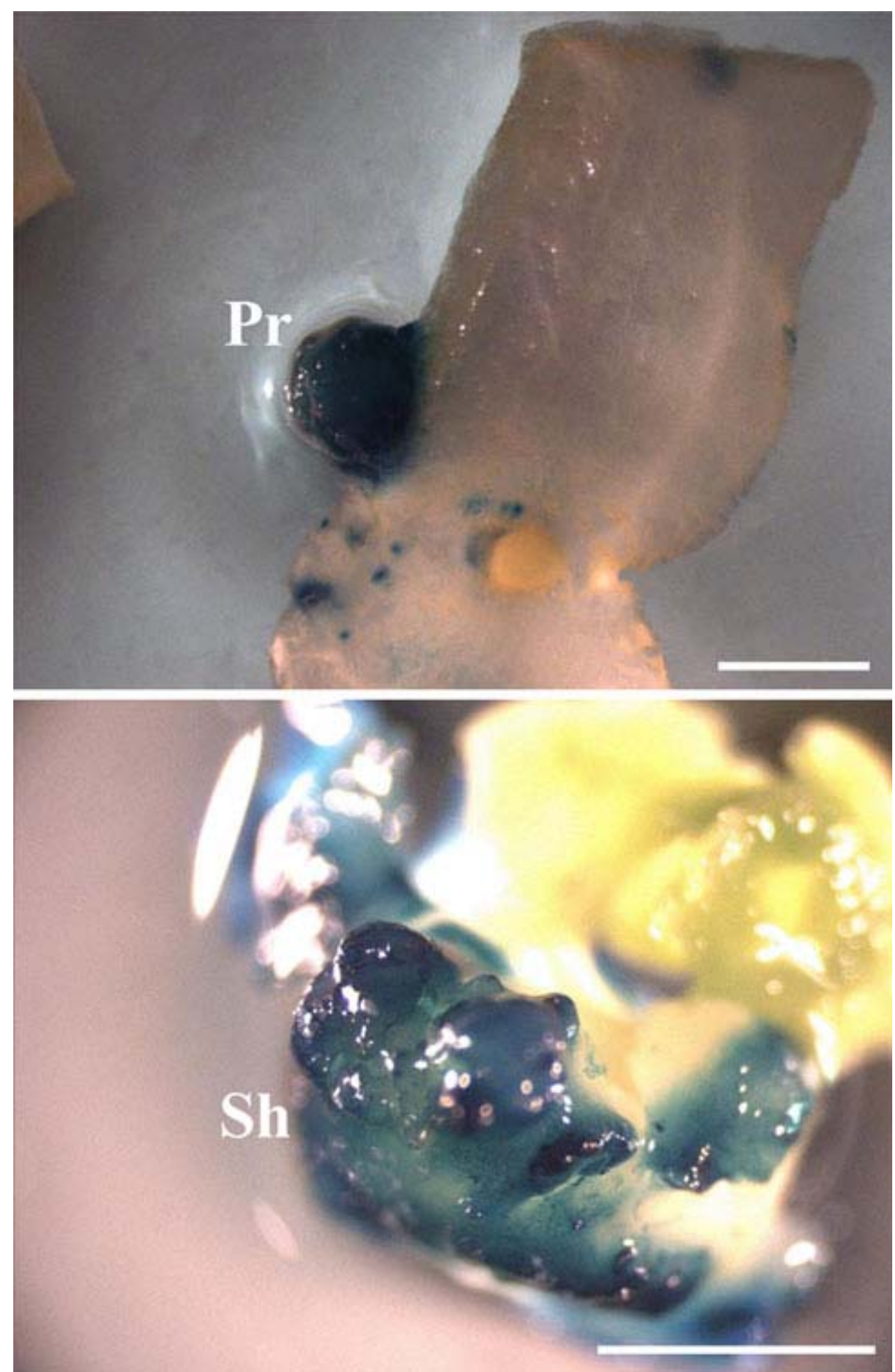

Fig. 1 GUS histochemical analysis on melon cotyledon explants 14 and 28 days after Agrobacterium exposure (GV2260pBI101) and culture on the regeneration medium. The presence of blue protuberances $(\mathrm{Pr})$ and shoots (Sh) expressing GUS activity was observed. Bar $0.5 \mathrm{~cm}$ 

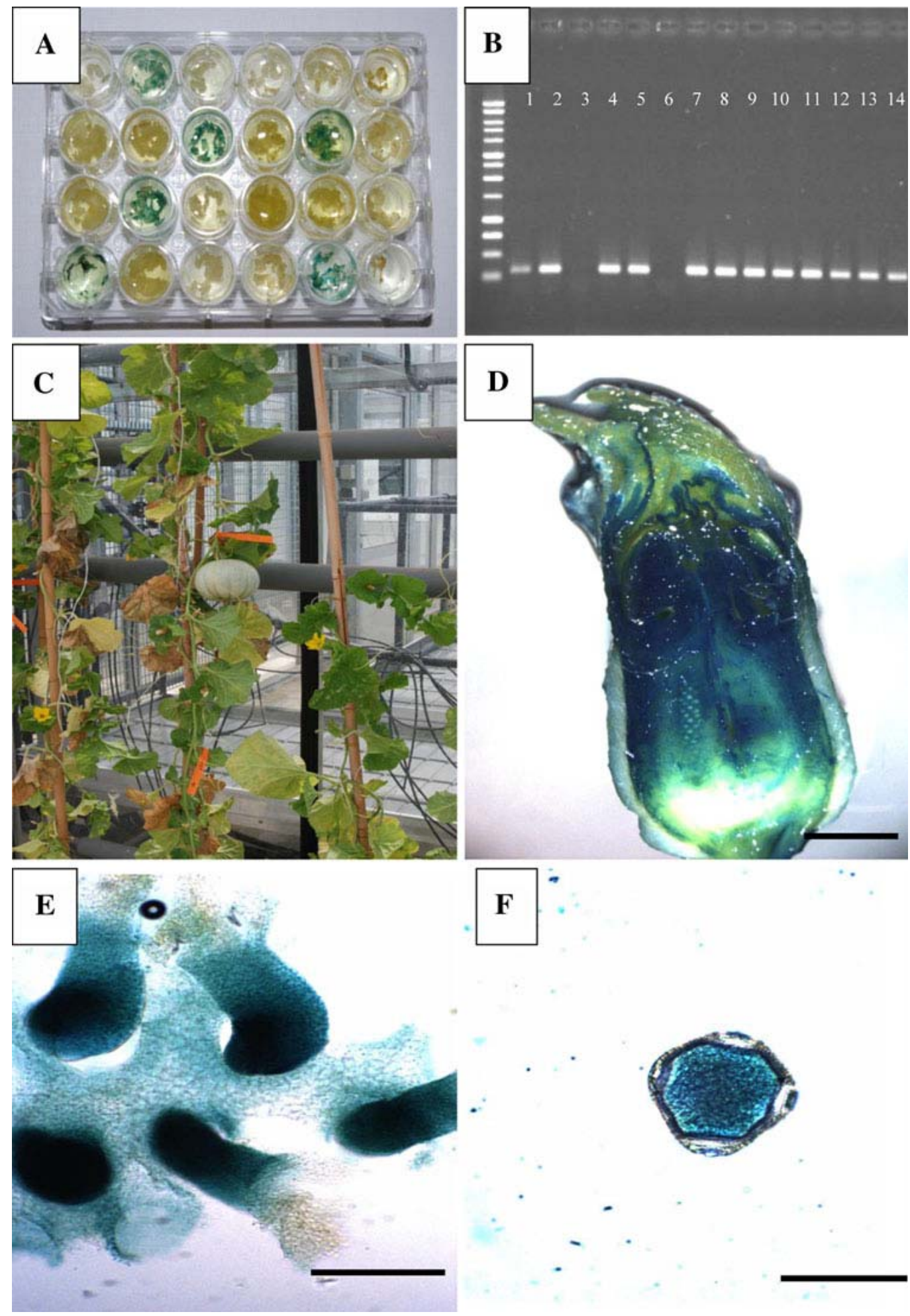

Fig. 2 Characterization of melon transgenic plants. a GUS histochemical analysis on leaf of in vitro plantlets. b Detection of NptII gene by PCR (amplified fragment $400 \mathrm{pb}$ ): (1 and 2) positive controls from Agrobacterium GV2260pBI101 and AGL-1pBI101 strains; (3) negative control from melon plant seedling; (4-14) melon plantlets obtained after transformation with GV2260pBI101. c Transgenic plants cultivated in greenhouse. d,e GUS activity in ovule and f pollen. Bar $30 \mu \mathrm{m}$ 

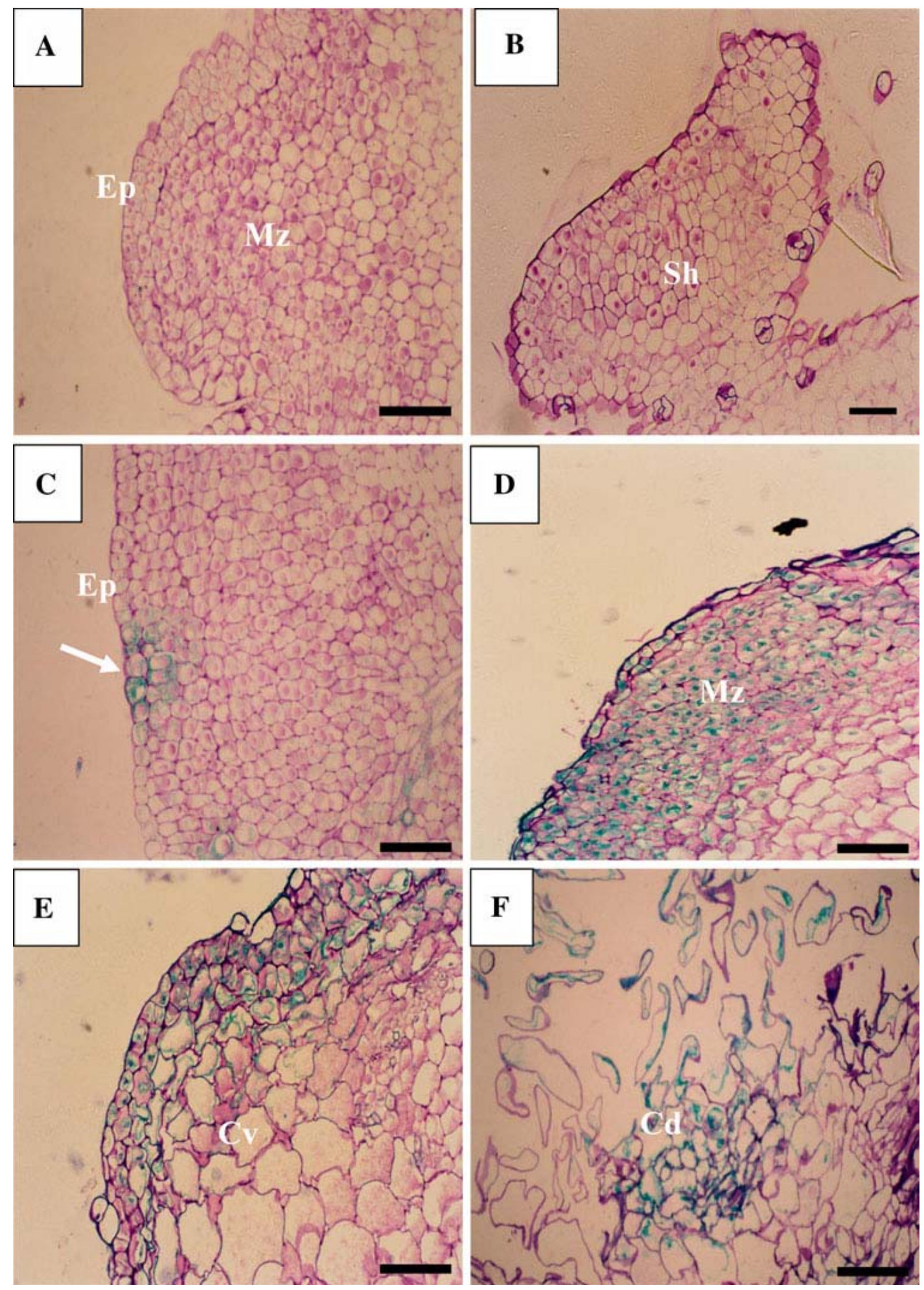

Fig. 3 Histological and morphological structures of melon cotyledon explants cultivated on regeneration medium.

Non-transformed explants: a development of the meristematic zone $(M z)$ from epidermis $(E p)$ at 14 days of culture and $\mathbf{b}$ shoots development (Sh) after 28 days.

Transformed explants: c,d GUS activity in meristematic structure 7 and 14 days after transformation with GV2260pBI101. e,f meristematic structure with cell vacuolization $(\mathrm{Cv})$ and cell dislocation (Cd) 28 days after transformation. Bar $100 \mu \mathrm{m}$ 


\section{References}

Aarrouf J, Garcin A, Lizzi Y, El-Maataoui M (2008) Immunolocalization and histocytopathological effects of Xanthomonas arboricola pv. pruni on naturally infected leaf and fruit tissues of peach (Prunus persica L. Batsch). J. Phytopathol. 165: 338-345

Abu-El-Heba GA, Hussein GM, Abdalla NA (2008) A rapid and efficient tomato regeneration and transformation system. Agric For Res 58:103-110

Adelberg JW, Rhodes BB, Skorupska HT, Bridges WC (1994) Explant origin affects the frequency of tetraploid plants from tissue-cultures of melon. HortScience 29:689-692

Akasaka-Kennedy Y, Tomita K, Ezura H (2004) Efficient plant regeneration and Agrobacterium-mediated transformation via somatic embryogenesis in melon (Cucumis melo L.) Plant Sci. 166:763-769

Anand A, Krichevsky A, Schornack S, Lahaye T, Tzfira T, Tang Y, Citovsky V, Mysore KS (2007) Arabidopsis VIRE2 INTERACTING PROTEIN2 is required for Agrobacterium T-DNA integration in plants. Plant Cell 19:1695-1708

Ayub R, Guis M, Ben Amor M, Gillot L, Roustan P, Latche A, Bouzayen M, Pech JC (1996) Expression of ACC oxidase antisense gene inhibits ripening of cantaloupe melon fruits. Nat Biotechnol. 14: 862-866

Bordas M, Montesinos C, Dabauza M, Salvador A, Roig AL, Serrano R, Moreno V (1997) Transfer of the yeast salt tolerance gene HAL1 to Cucumis melo L. cultivars and in vitro evaluation of salt tolerance. Transgenic Res 6: 41-50

Castelblanque L, Marfa V, Claveria E, Martinez I, Perez-Grau L, Dolcet-Sanjuan R (2008) Improving the genetic transformation efficiency of Cucumis melo subsp. melo 'Piel de Sapo' via Agrobacterium. In: Pitrat M (ed) Cucurbitaceae 2008, Proceeding of the IXth EUCARPIA meeting on genetics and breeding of Cucurbitaceae (), INRA, Avignon (France), May 21-24th 2008, pp 627-631

Chen WS, Chiu C, Liu HY, Lee TL, Cheng JT, Lin CC, Wu YJ, Chang HY (1998) Gene transfer via pollen-tube pathway for anti-fusarium wilt in watermelon. Biochem Mol Biol Int 46: 1201-1209

Curuk S, Cetiner S, Elman C, Xia X, Wang Y, Yeheskel A, Zilberstein L, Perl-Treves R, Watad AA, Gaba V (2005) Transformation of recalcitrant melon (Cucumis melo L.) cultivars is facilitated by wounding with carborundum. Eng. Life Sci 5:169-177

Davis WE, Miller AR, Linerberger RD (1992) Studies on the effects of ethylene on transformation of tomato cotyledons (Lycopersicon esculentum Mill.) by Agrobacterium tumefaciens. J Plant Physiol 139:302-309

Dong JZ, Yang MZ, Jia SR Chua NH (1991) Transformation of melon (Cucumis melo L.) and expression from the cauliflower mosaic virus-35S promoter in transgenic melon plants. Bio-Technology 9:858-863

Ezura H, Amagai H, Yoshioka K, Oosawa K (1992) Highly frequent appearance of tetraploidy in regenerated plants, a universal phenomenon in tissue-cultures of melon (Cucumis melo L.). Plant Sci 85: 209-213

Ezura H, Hitomi A, Higashi K, Sato T, Kubota M (1997) Introduction of ACC synthase antisense gene to muskmelon (Cucumis melo L. var. reticulatus). In: Abak K, Buyukalaca S (eds) First international Symposium on Cucurbits, Adana, Turkey, Abstract

Ezura H, Yuhashi K-I, Yasuta T, Minamisawa K (2000) Effect of ethylene on Agrobacterium tumefaciens-mediated gene transfer to melon. Plant Breed 119: 75-79

Fang GW, Grumet R (1990) Agrobacterium tumefaciens mediated transformation and regeneration of muskemelon plants. Plant Cell Rep 9:160-164

Fang GW, Grumet R (1993) Genetic-engineering of potyvirus resistance using constructs derived from the zucchini yellow mosaic virus coat protein gene. Mol Plant Microbe Interact 6:358-367 
Fuchs M, Mc-Ferson JM, Tricoli DM, Mc-Master JR, Deng RZ, Boeshore ML, Reynolds JF, Russell PF, Quemada HD, Gonsalves D (1997) Cantaloupe line CZW-30 containing coat protein genes of cucumber mosaic virus, zucchini yellow mosaic virus, and watermelon mosaic virus-2 is resistant to these three viruses in the field. Mol Breed 3: 279-290

Fulton TM, Chunwongse J, Tanksley SD (1995) Microprep protocol for extraction of DNA from tomato and other herbaceous plants. Plant Mol Biol Rep 13: 207-209

Gaba V, Kless H, Antignus L (1992) Transformation of melon by particle acceleration. Suppl Plant Physiol 99:137-137

Gaba V, Schlarman E, Elman C, Sagee O, Watad AA, Gray DJ (1999) In vitro studies on the anatomy and morphology of bud regeneration in melon cotyledons. In vitro Cell Dev Biol Plant 35:1-7

Gaba V, Zelcer A, Gal-on A (2004) Cucurbit technology - The importance of virus resistance. In Vitro Cell Dev Biol Plant 40:346-358

Galbraith DW, Harkins K, Knapp S (1991) Systemic endopolyploidy in Arabidopsis thaliana. Plant Physiol 96:985-989

Galperin M, Patlis L, Ovadia A, Wolf D, Zelcer A, Kenigsbuch D (2003) A melon genotype with superior competence for regeneration and transformation. Plant Breed 122:66-69

Gelvin SB (2003) Agrobacterium-mediated plant transformation: the biology behind the gene jockey tool. Microbiol Mol Biol Rev 67:16-37

Gonsalves C, Xue B, Yepes M, Fuchs M, Ling KS, Namba S, Chee P, Slightom JL, Gonsalves D (1994) Transferring cucumber mosaic virus-white leaf strain coat protein gene into Cucumis melo L. and evaluating transgenic plants for protection against infections. J Am Soc Hortic Sci 119:345-355

Gray D, Hiebert E, Kelley KT, Compton ME, Gaba VP (1995) Comparison of methods to transform embryogenic cotyledons of melon. Hortscience 30:788-788

Guis M, Latche A, Pech JC, Roustan JP (1997) An efficient method for production of diploid cantaloupe charentais melon (Cucumis melo L. var. cantaloupensis) by somatic embryogenesis. Sci Hortic 69: 199-206

Guis M, Amor MB, Latche A, Pech JC, Roustan JP (2000) A reliable system for the transformation of cantaloupe charentais melon (Cucumis melo L. var. cantalupensis) leading to a majority of diploid regenerants. Sci Hortic 84:91-99

Han JS, Kim CK, Park SH, Hischi KD, Mok IG (2005) Agrobacterium-mediated transformation of bottle gourd (Lagenaria siceraria Standl.). Plant Cell Rep 23:692-698

Hansen G (2000) Evidence for Agrobacterium-induced apoptosis in maize cells. Mol. Plant Microbe Interact 13:649-657

Hao J, Niu Y, Yang B, Gao F, Zhang L, Wang J, Hasi A (2010) Transformation of a markerfree and vector-free antisense ACC oxidase gene cassette into melon via the pollen-tube pathway. Biotechnol Lett 33:55-61

Hellens R, Mulineaux P, Klee H (2000) A guide to Agrobacterium binary Ti vectors. Trends Plant Sci 5:446-451

Huttner E, Tucker W, Vermeulen A, Ignart F, Sawyer B, Birch R (2001) Ribozyme genes protecting transgenic melon plants against potyviruses. Curr Issues Mol Biol 3:27-34

Jefferson RA, Kavanagh TA, Bevan MW (1987) GUS fusions: $\beta$-glucuronidase as a sensitive and versatile gene fusion marker in higher plants. EMBO J 6:3901-3907

Khanna HK, Paul JY, Harding RM, Dickman MB, Dale JL (2007) Inhibition of Agrobacterium-induced cell death by antiapoptotic gene expression leads to very high transformation efficiency of banana. MPMI 20:1048-1054

Kintzios S, Sereti E, Bluchos P, Drossopoulos JB, Kitsaki CK, Liopa-Tsakalidis A (2002) Growth regulator pre-treatment improves somatic embryogenesis from leaves of squash (Cucurbita pepo L.) and melon (Cucumis melo L.). Plant Cell Rep 21:1-8 
Liborio Stipp LC, Januzzi Mendes BM, Stefano Piedade SMD, Martinelli Rodriguez AP (2001) In vitro morphogenesis of Cucumis melo var. inodorus. Plant Cell Tissue Organ Cult 65:81-89

Lippincott BB, Whatley MH, and Lippincott JA (1977) Tumor induction by Agrobacterium involves attachment of bacterium to a site on host plant-cell wall. Plant Physiol 59:388390

Martin A, Troadec C, Boualem A, Rajab M, Fernandez R, Morin H, Pitrat M, Dogimont C, Bendahmane A (2009) A transposon-induced epigenetic change leads to sex determination in melon. Nature 461:1135-1138

Murashige T, Skoog F (1962) A revised medium for rapid growth and bioassays with tobacco tissue cultures. Physiol Plant 15:473-497

Nam J, Matthysse AG, Gelvin, SB (1997) Differences in susceptibility of Arabidopsis ecotypes to crown gall disease may result from a deficiency in T-DNA integration. Plant Cell 9:317-333

Ntui VO, Khan RS, Chin DP, Nakamura I, Mii M (2010) An efficient Agrobacterium tumefaciens-mediated genetic transformation of Egusi melon (Colocynthis citrullus L.) Plant Cell Tiss Organ Cult 103: 15-22

Nugent PE (1994) Tetraploid 'planters Jumbo' melon lines C883-M6-4x. HortScience 29:4748

Nunez-Palenius HG, Cantliffe DJ, ·Huber DJ, Ciardi J, Klee HJ (2006) Transformation of a muskmelon 'Galia' hybrid parental line (Cucumis melo L. var. reticulatus Ser.) with an antisense ACC oxidase gene. Plant Cell Rep 25: 198-205

Nunez-Palenius HG, Gomez-Lim M, Ochoa-Alejo N (2008) Melon fruits: genetic diversity, physiology and biotechnology features. Biotechnology 28:13-55

Papadopoulou E, Little HA, Hammar SA, Grumet R (2005) Effect of modified endogenous ethylene production on sex expression, bisexual flower development and fruit production in melon (Cucumis melo L.). Sex Plant Reprod 18:131-142

Pech JC, Bernadac A, Bouzayen M, Latche A, Dogimont C, Pitrat M (2007) Melon. Biotechnology in Agriculture and Forestry. In: Pua EC, Davey MR (eds) Transgenic Crops V. vol 60. chap I.9, pp 209-240

Schulze J, Balko C, Zellner, Koprek T, Hansch R, Nerlich A, Mendel RR (1995) Biolistic transformation of cucumber using embryogenic suspension cultures: long-term expression of reporter genes. Plant Science 112:197-206

Silva JA, da Costa TS, Lucchetta L, Marini L,J, Zanuzo MR, Nora L, Nora FR, Twyman RM, Rombaldi CV (2004) Characterization of ripening behavior in transgenic melons expressing an antisense 1-aminocyclopropane-1-carboxylate (ACC) oxidase gene from apple. Postharvest Biol Tex 32:263-268

Veena Jiang, H, Doerge RW, Gelvin SB (2003) Transfer of TDNA and Vir proteins to plant cells by Agrobacterium tumefaciens induces expression of host genes involved in mediating transformation and suppresses host defence gene expression. Plant J 35:219236

Wolf D, Matzevitch T, Steinitz B, Zelcer A (2001) Why is it difficult to obtain transgenic pepper plant? In: Sorvari S et al (eds) Proc.IV IS on In Vitro Cult \& Hort Breeding ISHS, Leuven, pp 229-233

Wu HW, Yu TA, Raja JAJ, Christopher SJ, Wang SL, Yeh SD (2010) Double-virus resistance of transgenic oriental melon conferred by untranslatable chimeric construct carrying partial coat protein genes of two viruses. Plant Dis 94: 1341-1347

Yalcin-Mendi NY, Ipek M, Kacan H, Curuk S, Sari N, Cetiner S, Gaba V (2003) A histological analysis of regeneration in watermelon. J. Plant Biochem Biotechnol 12:147-150

Yalcin-Mendi NY, Ipek M, Serbest-Kobaner S, Curuk S, Aka Kacar Y, Cetiner S, Gaba V, Grumet R (2004) Agrobacterium-mediated transformation of Kirkagac 637 a 
recalcitrant melon (Cucumis melo) cultivar with ZYMV coat protein encoding gene. Eur J Hortic Sci 69:258-262

Yang AF, Su Q, An LJ, Liu JF, Wu W, Qiu Z (2009) Detection of vector-and selectable marker-free transgenic maize with a linear GFP cassette transformation via the pollentube pathway. J Biotechnol 139:1-5

Yee S, Stevens B, Coleman S, Seabrook J, Li X (2001) High-efficiency regeneration in vitro from potato petioles with intact leaflets. Am J Potato Res 78:151-157

Yoshioka K, Hanada K, Harada T, Minobe Y, Oosawa K (1993) Virus-resistance in transgenic melon plants that express the cucumber mosaic-virus coat protein gene and in their progeny. Jpn J Breed 43:629-634

Zhou GY, Weng J, Zeng YS, Huang JG, Qian SY, Liu GL (1983) Introduction of exogenous DNA into cotton embryos. Meth Enzymol 101:433-481 